\title{
PENYELESAIAN SENGKETA PERTANAHAN MELALUI MEDIASI BERDASARKAN TEORI DEAN G.PRUITT DAN JEFFREY Z.RUBIN
}

\author{
Juwita Tarochi Boboy, Budi Santoso, Irawati \\ Program Studi Magister Kenotariatan \\ Fakultas Hukum, Universitas Diponegoro \\ Email : juwitaboboy861@gmail.com
}

\begin{abstract}
The State of Indonesia is an agricultural country, so land has a very important meaning for the lives of the people of Indonesia. Once the importance of the position of land for humans is not uncommon to cause disputes about land. Theoretically, dispute resolution can be done in 2 (two) ways, namely through formal justice mechanisms in the court (litigation) and outside the judicial process (non litigation). One form of settlement outside the court is Mediation. Mediation is the settlement of disputes through negotiations with the help of a neutral third party (mediator) in order to find a form of settlement that can be agreed by the parties.Mediation is basically a deliberation and consensus, namely as a way or process other than other ways or processes either through arbitration, negotiation, conciliation, and others. If there is an agreement in mediation, and is stated in a peace deed, this peace deed is actually a legal product and has binding power as the characteristics of the consensual principle according to Article 1338 of the Civil Code. Accordingly, agreements made legally, act as laws for the parties to the dispute. This Articel is a analytical descriptive social legal approach through the qualitative methods.
\end{abstract}

\section{Keywords : dispute resolution; mediation}

\begin{abstract}
Abstrak
Negara Indonesia merupakan salah satu negara agraris, sehingga tanah mempunyai arti yang sangat penting bagi kehidupan rakyat Indonesia. Begitu pentingnya kedudukan tanah bagi manusia tidak jarang menyebabkan terjadinya sengketa tentang tanah. Secara teoritis penyelesaian sengketa dapat dilakukan melalui 2 (dua) cara, yaitu melalui mekanisme peradilan formal dalam pengadilan (litigasi) dan diluar proses peradilan (non litigasi). Salah satu bentuk penyelesaian diluar pengadilan adalah Mediasi. Mediasi merupakan penyelesaian sengketa melalui perundingan dengan bantuan pihak ketiga netral (mediator) guna mencari bentuk penyelesaian yang dapat disepakati para pihak.Mediasi pada dasarnya adalah musyawarah dan mufakat, yakni sebagai suatu cara atau proses selain cara atau proses lainnya baik melalui arbitrase, negosiasi, konsiliasi, dan lain-lainnya. Jika secara mediasi terdapat kata sepakat, dan dituangkan dalam suatu akta perdamaian, sebenarnya akta perdamaian ini adalah produk hukum dan memiliki kekuatan mengikat sebagaimana karakteristik asas konsensual menurut Pasal 1338 Kitab Undang-undang Hukum Perdata. Dengan demikian, kesepakatan yang dibuat secara sah, berlaku sebagai Undang-undang bagi para pihak yang bersengketa. Artikel ini menggunakan pendekatan socio legal secara deskriptif analitis melalui metode kualitatif.
\end{abstract}

Kata kunci : penyelesaian sengketa; mediasi 


\section{A. Pendahuluan}

Sengketa dapat terjadi pada setiap pihak, mulai dari antara individu maupun kelompok, kombinasi keduanya, hingga antara perusahaan, perusahaan dengan negara, bahkan sesama negara, dan sebagainya. Dengan kata lain, sengketa dapat bersifat publik maupun bersifat keperdataan dan dapat terjadi dalam lingkup lokal, nasional, hingga internasional.

Sengketa adalah sesuatu yang menyebabkan perbedaan pendapat, pertengkaran, pembantahan, pertikaian, perselisihan, perkara (Departemen Pendidikan Nasional, 2015: 1272). Sengketa atau konflik merupakan bentuk aktualisasi atas perbedaan kepentingan diantara kedua belah pihak atau lebih (Sutiyoso, 2006). Suatu situasi dimana kedua belah pihak atau lebih dihadapkan pada perbedaan kepentingan, tidak akan berkembang menjadi suatu sengketa apabila pihak yang merasa dirugikan hanya memendam perasaan tidak puas atau keprihatinannya. Sebuah situasi berubah atau berkembang menjadi sebuah sengketa apabila pihak yang merasa dirugikan menyatakan rasa tidak puas atau keprihatinannya, secara langsung maupun tidak langsung kepada pihak penyebab kerugian atau pihak lain (Usman, 2002).

Munculnya sengketa yang berkepanjangan mendorong umat manusia mencari jalan penyelesaian yang humanist, mudah, dan adil, dimana kedua belah pihak tidak merasa dirugikan (win-win solution). Namun kenyataannya, mekanisme hukum kontinental yang ada selama ini tidak mampu mengakomodir keinginan manusia, sehingga hampir setiap permasalahan sengketa yang diselesaikan melalui pengadilan cenderung menguntungkan satu pihak (win and lose solution) dan juga mahal. Berbagai penelitian dan inovasi dilakukan banyak pakar hukum untuk mengekspresikan beragam model penyelesaian sengketa sebagai cita-cita yang luhur untuk mencapai perdamaian, antara lain sebagai berikut:

“Undang-undang Dasar Tahun 1945 menyatakan, ”Bumi dan air dan kekayaan alam yang terkandung di dalamnya dikuasai oleh negara dan dipergunakan untuk sebesarbesar kemakmuran rakyat". Secara konstitusional dalam Undang-undang Dasar 1945 Pasal 33 ayat (3) telah memberikan landasan bahwa bumi dan air serta kekayaan alam yang terkandung didalamnya dikuasi Negara dan dipergunakan untuk sebesarbesarnya kemakmuran rakyat" (Effendie, 1983).

"Tanah memiliki arti yang sangat penting bagi setiap individu dalam masyarakat. Selain memiliki nilai ekonomis yang dapat dicadangkan sebagai sumber pendukung kehidupan manusia di masa mendatang, tanah mengandung aspek spiritual dalam lingkungan dan kelangsungan hidupnya. Tanah merupakan tempat pemukiman, tempat 
melakukan kegiatan manusia bahkan sesudah matipun masih memerlukan tanah (Chulaemi, 1992). Timbulnya sengketa hukum mengenai tanah berawal dari pengaduan suatu pihak (orang atau badan hukum) yang berisi keberatan-keberatan dan tuntutan hak atas tanah baik terhadap status tanah, prioritas maupun kepemilikannya dengan harapan dapat memperoleh penyelesaian secara administrasi sesuai dengan ketentuan peraturan yang berlaku" (Murad, 1991: 22).

Problematika tanah merupakan isu yang menjadi skala prioritas untuk diselesaikan. Ketidakmampuan lembaga peradilan untuk menangani berbagai sengketa bidang pertanahan, mengakibatkan kepercayaan masyarakat berkurang. Oleh karena itu, diperlukan suatu alternatif untuk menanggulangi sengketa pertahanan.

Permasalahan pertanahan hingga kini merupakan fenomena yang kerap muncul dan aktual dari masa ke masa. Seiring pertambahan penduduk, perkembangan pembangunan, dan semakin meluasnya akses berbagai pihak yang memperoleh tanah sebagai modal dasar dalam berbagai kepentingan (Pahlefi, 2014). Permasalahan bidang pertanahan dipengaruhi berbagai faktor, kebutuhan akan tanah menjadi hal yang tidak bisa dihindari. Kenyataan ini mengakibatkan permasalahan di bidang pertanahan menjadi eskalasi tinggi. Salah satu bentuk permasalahan yang umumnya adalah tumpang tindih lahan atau sering disebut masyarakat dengan sertifikat ganda. Berbagai cara dilakukan masyarakat untuk menemukan solusi agar permasalahan tersebut dapat diatasi, sehingga tanah dapat dimanfaatkan secara ekonomi.

\section{- Kerangka Teori}

Sebagaimana diketahui, terdapat beragam saluran yang dapat ditempuh setiap pihak yang bersengketa untuk mendapatkan solusi dari sengketa pertanahan. Para pihak yang berperkara dapat menempuh jalur litigasi dan/ atau non litigasi. Jalur litigasi melalui lembaga peradilan yaitu Peradilan Umum dan Peradilan Tata Usaha Negara. Sedangkan jalur non litigasi dapat ditempuh dengan rekonsiliasi, negosiasi, arbitrase, dan mediasi.

Mediasi merupakan proses penyelesaian sengketa antara dua pihak atau lebih melalui perundingan atau cara mufakat dengan bantuan pihak netral (pihak ketiga) yang tidak memiliki kewenangan memutus (Rahmadi, 2010). Mediasi sebagai salah satu bentuk atau cara penyelesaian sengketa dapat ditemukan dalam beberapa peraturan perundanganundangan dalam berbagai bentuk konteks sengketa (Asmawati, 2004).

Regulasi tentang mediasi pertama kali diatur melalui rumusan Undang-undang No. 30 Tahun 1999 tentang Arbitrase dan Alternatif Penyelesaian Sengketa. Tetapi, Undang-undang ini tidak membahas prosedur pelaksanaan mediasi secara detail. Hingga pada tahun 2003 
Mahkamah Agung RI menerbitkan Peraturan Mahkamah Agung RI Nomor 1 Tahun 2008 tentang Prosedur Mediasi di Pengadilan sebagaimana telah disempurnakan melalui Peraturan Mahkamah Agung RI Nomor 1 tahun 2016.

Mediasi merupakan cara penyelesaian sengketa secara damai yang tepat, efektif, dan dapat membuka akses yang lebih luas kepada Para Pihak untuk memperoleh penyelesaian yang memuaskan serta berkeadilan; bahwa dalam rangka reformasi birokrasi Mahkamah Agung Republik Indonesia yang berorientasi pada visi terwujudnya badan peradilan indonesia yang agung, salah satu elemen pendukung adalah Mediasi sebagai instrumen untuk meningkatkan akses masyarakat terhadap keadilan sekaligus implementasi asas penyelenggaraan peradilan yang sederhana, cepat, dan berbiaya ringan.

Salah satu solusi alternatif untuk menyelesaikan sengketa pertanahan dengan melalui mediasi, yang difasilitasi oleh kantor pertanahan, tujuan dari pada penyelesaian melalui mediasi ini adalah selain permasalahan sengketa pertanahan dapat diselesaikan, disisi lain mediasi dipilih karena dianggap lebih efektif untuk mengatasi soal pembiayaan litigasi yang besar, penundaan perkara yang berlarut-larut dan tidak efisiennya litigasi, waktu singkat, dengan sebuah syarat bahwa para pihak dalam sengketa pertanahan dapat menerima dengan rasa keadilan (Gautama, 1996).

\section{- Permasalahan}

Dari latar belakang tersebut di atas, maka permasalahan yang hendak diteliti melalui artikel ini adalah : Penyelesaian sengketa pertanahan di luar pengadilan melalui mediasi berdasarkan teori penyelesaian sengketa Dean G Pruitt dan Jeffrey Z. Rubin'.

\section{- Kebaruan/ Orisinalitas Hasil Penelitian}

Untuk memperkuat hasil artikel kelak, dibutuhkan kajian terhadap tulisan terdahulu yang dapat memaksimalkan artikel yang penulis susun. Kemudian diiringi penjabaran faktor pembeda antara fokus artikel penulis dan sebelumnya melalui suatu rujukan tertentu. Artikel yang menjadi rujukan penulis adalah sebagaimana dikemukakan di bawah ini:

Artikel Pertama, Mediasi Sosial Dalam Menyelesaikan Konflik Lahan Milik Masyarakat Adat Di Indonesia, ditulis oleh Firman Freaddy Busroh Sekolah Tinggi Ilmu Hukum Sumpah Pemuda (STIHPADA) Palembang, fokus studynya tentang mediasi sosial dalam menyelesaikan konflik lahan milik masyarakat adat dan metode yang digunakan ialah yuridis normatif. Artikel kedua, Mediasi Salah Satu Cara Dalam Penyelesaian Sengketa Pertanahan. focus studynya tentang proses mediasi dalam sengketa pertanahan (umum) dan kekuatan hukum kespakatan mediasi dalam sengketa pertanahan, metode yang digunakan 
ialah yuridis normatif, sedangkan aritikel yang saya tulis ialah Penyelesaian Sengketa Pertanahan Melalui Mediasi Berdasarkan Teori Dean G. Pruitt dan Jeffrey Z.Rubin, fokus studynya mediasi penyelesaian sengketa pertanahan masyarakat indonesia (umum) dan metode yang digunakan ialah metode socio legal secara deskriptif analitis melalui metode kualitatif.

\section{B. Metode Penelitian}

Metode pendekatan dilakukan melalui socio legal dengan mengkaji pelaksanaan atau implementasi ketentuan hukum positif (peraturan perUndang-undangan) dan kontrak secara faktual pada setiap peristiwa hukum tertentu yang terjadi didalam masyarakat guna mencapai tujuan yang telah ditentukan (Muhammad, 2004), dan teori-teori hukum serta yurisprudensi terkait permasalahan yang dibahas (Soemitro, 1998). Sementara itu spesifikasi artikel ini deskriptif analitis yang kemudian dianalisis menurut ilmu dan teori yang ada serta pendapat penulis sendiri untuk menyimpulkannya (Achmad, 2013). Teknik atau metode Analisis Data dilakukan melalui metode kualitatif, untuk kemudian diolah dengan proses editing, dan selanjutnya dianalisis secara kualitatif melalui wawancara terhadap narasumber, untuk menemukan kesimpulan atas jawaban dari permasalahan artikel.

\section{Hasil Dan Pembahasan}

\section{Teori Penyelesaian Sengketa berdasarkan teori dari Dean G. Pruitt dan Jeffrey Z.}

\section{Rubin}

Dalam perkembangan ilmu pengetahuan dan teknologi sekarang ini, teori yang dikemukakan oleh para ahli sering dijadikan acuan dalam memecahkan masalah yang hidup dan berkembang di dalam kehidupan masyarakat. Kata teori berasal dari kata theoria yang artinya pandangan atau wawasan (Mertokusumo, 2012). Pada umumnya, teori diartikan sebagai pengetahuan yang hanya ada dalam alam pikiran tanpa dihubungkan dengan kegiatan-kegiatan yang bersifat praktis untuk melakukan sesuatu.

Teori penyelesaian sengketa merupakan teori yang mengkaji dan menganalisis tentang kategori atau penggolongan sengketa atau pertentangan yang timbul dalam masyarakat, faktor penyebab terjadinya sengketa dan cara-cara atau strategi yang digunakan untuk mengakhiri sengketa tersebut. Dean G Pruitt dan Jeffrey Z. Rubin mengemukakan teori tentang penyelesaian sengketa. Ada 5 (lima), yaitu: (Pruitt. Dean G \& Z. Rubin, 2004).

a. Contending (bertanding), yaitu mencoba menerapkan suatu solusi yang lebih disukai oleh salah satu pihak atas pihak yang lainnya. 
b. Yielding (mengalah), yaitu menurunkan aspirasi sendiri dan bersedia menerima kekurangan dari yang sebetulnya diinginkan.

c. Problem solving (pemecahan masalah), yaitu mencari alternatif yang memuaskan dari kedua belah pihak.

d. With drawing (menarik diri), yaitu memilih meninggalkan situasi sengketa, baik secara fisik maupun psikologis.

e. In action (diam), yaitu tidak melakukan apa-apa.

Dalam literatur, Teori Penyelesaian Sengketa juga dinamakan dengan Teori Konflik. Konflik dalam kamus bahasa Indonesia adalah percekcokan, perselisihan dan pertentangan. Konflik adalah perbedaan pendapat dan perselisihan paham antara dua pihak tentang hak dan kewajiban pada saat dan dalam keadaan yang sama. Pengertian Konflik itu sendiri dirumuskan oleh Dean G. Pruitt dan Jeffrey Z. Rubin bahwa, konflik adalah persepsi mengenai perbedaan kepentingan (perceived divergence of interest), atau suatu kepercayaan bahwa aspirasi pihak-pihak yang berkonflik tidak dicapai secara simultan (secara serentak) (Talib, 2013).

Pruitt dan Rubin merumuskan konflik sebagai perbedaan kepentingan atau tidak dicapainya kesepakatan para pihak. Maksud Perbedaan kepentingan adalah berlainannya keperluan atau kebutuhan masing-masing pihak. Misalnya, A. sebagai salah satu ahli waris, menginginkan rumah warisan yang ditinggalkan oleh pewaris dijual, sementara pihak B tidak menginginkan rumah itu dijual karena mengandung nilai-nilai sejarah bagi keluarga.

Sengketa merupakan bagian dari kehidupan sosial, akan selalu hadir seiring dengan keberadaan manusia dalam menjalankan aktivitasnya yang selalu bersentuhan dengan sesamanya secara individu maupun kelompok. Kovach mendefinisikan konflik sebagai suatu perjuangan mental dan spiritual manusia yang menyangkut perbedaan berbagai prinsip, pernyataan dan argumen yang berlawanan (Absori, 2014).

Berpangkal dari terjadinya konflik, maka muncul pekermbangan dua teori konflik, yaitu teori Fungsionalisme Struktural dan Teori Pendekatan Konflik, yaitu : (Busroh, 2017).

a. Teori Fungsionalisme Struktural mengemukakan bahwa masyarakat pada dasarnya terintegrasi di atas dasar "kata sepakat" para anggotanya akan nilai-nilai kemasyarakatan tertentu. Teori ini dapat mengatasi perbedaan-perbedaan pendapat dan kepentingan di antara para anggota masyarakat. Dalam hal ini, masyarakat adalah suatu sistem yang secara fungsional terintegrasi ke dalam suatu bentuk equilibrium. Masyarakat, harus dipandang sebagai suatu sistem dari bagian-bagian yang saling berhubungan satu 
terhadap yang lain. Karena itu, hubungan saling mempengaruhi di antara bagian-bagian tersebut bersifat ganda dan timbal balik. Melalui teori ini dikatakan bahwa sekalipun integrasi sosial tidak pernah dapat dicapai dengan sempurna, namun secara fundamental sistem sosial selalu cenderung bergerak ke arah equilibrium yang bersifat dinamis. Integrasi sosial dapat menanggapi perubahan-perubahan yang datang dari luar dengan kecenderungan memelihara agar perubahan-perubahan yang terjadi dalam sistem sebagai akibatnya hanya akan mencapai derajat yang minimal. Meskipun terjadi disfungsi, ketegangan-ketegangan dan penyimpangan-penyimpangan melalui proses panjang teratasi dengan sendirinya melalui penyesuaian-penyesuaian dan proses institusionalisasi. Dengan kata lain, integrasi sosial pada tingkatnya yang sempurna tidak akan pernah tercapai, namun setiap sistem soaial akan senantiasa berproses ke arah sana.

b. Teori Pendekatan Teori Konflik, yang beranggapan bahwa, setiap masyarakat senantiasa berubah dan perubahan itu tidak pernah berakhir karena perubahan sosial merupakan gejala yang inheren pada setiap masyarakat, setiap masyarakat mengandung konflik di dalam dirinya karena konflik merupakan gejala yang inheren pada setiap masyarakat, setiap unsur dalam masyarakat memberi kontribusi terjadinya disintegrasi dan perubahanperubahan sosial, dan setiap masyarakat terintegrasi atas penguasaan dan dominasi sejumlah orang terhadap sejumlah orang yang lain. Dengan kata lain, konflik bersumber dari masyarakat itu sendiri. Konflik timbul dari realitas adanya unsur-unsur yang saling bertentangan dalam masyarakat secara internal yang terjadi akibat pembagian otoritas tidak merata. Oleh karena itu, terdapat pola pemisahan antara masyarakat yang memiliki otoritas dan yang tidak memilikinya.

Pembagian otoritas yang dikotomis merupakan faktor pemicu timbulnya konflik sosial dalam masyarakat. Pembagian kekuasaan dapat menimbulkan kepentingan-kepentingan yang berlawanan antara satu dan lainnya. Pihak yang menempati posisi sebagai pemegang otoritas dan yang tidak memiliki otoritas, memiliki kepentingan yang berlawanan satu sama lainnya. Pihak yang memiliki otoritas cenderung mengukuhkan status quo, sedangkan yang tidak memiliki otoritas akan berusaha mengubah status quo mereka.

Dampaknya, semakin bertambahnya otoritas pada satu pihak, semakin berkurang pula otoritas pada pihak yang lain. Konsep tersebut menegaskan bahwa pendekatan konflik merupakan suatu gejala yang serba hadir dalam setiap masyarakat dan selalu inheren dalam diri setiap masyarakat. Konsep atau model ideal kebijakan dapat dilakukan hanya untuk mengatur dan mengendalikan konflik yang terjadi agar tidak akan terbentuk dalam 
kekerasan (violence) serta berkepanjangan tanpa penyelesaian yang mampu memberikan kepastian dan perlindungan hukum. Dalam kaitan dengan konflik agraria/pertanahan, teori tentang konflik sangat relevan sebagai salah satu konsep guna mendukung model-model yang dianggap lebih layak. Hal tersebut, karena masalah sengketa pertanahan merupakan salah satu masalah yang sering muncul dan cenderung disertai tindakan kekerasan.

Penyelesaian terhadap kasus-kasus terkait sengketa perdata pada umumnya ditempuh melalui jalur pengadilan yang dapat dipastikan memerlukan waktu dan biaya yang tidak sedikit. Sebenarnya terdapat jalur penyelesaian lain yang belum banyak diketahui masyarakat luas yaitu mediasi di kantor pertanahan setempat. Dalam perkembangannya, mediasi mulai sering dijadikan salah satu pilihan dalam menyelesaian sengketa di bidang pertanahan (Irzan, 2012).

\section{Penyelesaian Sengketa Pertanahan Melalui Mediasi Dean G. Pruitt dan Jeffrey Z.}

\section{Rubin}

Konflik dan sengketa pertanahan di Indonesia bersifat multi-dimensional. Maka, usaha pencegahan, penanganan, dan penyelesaian sengketa harus memperhitungkan aspek hukum dan non-hukum. Sengketa yang kerap terjadi dalam sorotan artikel ini terutama adalah Sengketa waris, yaitu perbedaan persepsi, nilai atau pendapat, kepentingan mengenai status penguasaan di atas tanah tertentu yang berasal dari warisan.

Mencermati masalah pertanahan yang semakin kompleks dan meningkat secara kualitas maupun kuantitas, maka diperlukan penanganan serius dan sistematis. Penyelesaian sengketa pertanahan melalui proses litigasi (peradilan) yang ada dianggap belum mampu menyelesaikan sengketa, sehingga dibutuhkan beragam upaya alternatif penyelesaian sengketa pertanahan di luar pengadilan (Non-Ligitasi). Mulai dari melalui mediasi, fasilitasi, dan lainnya untuk meminimalisir sengketa pertanahan yang sarat dengan kepentingan pembangunan maupun masyarakat sendiri.

Badan Pertanahan Nasional (BPN) telah menerbitkan Keputusan Kepala Badan Pertanahan Nasional RI No. 11 tahun 2009 tentang Kebijakan dan Strategis Kepala BPN RI Menangani dan Menyelesaikan Sengketa, Konflik dan Perkara Pertanahan tahun 2009, dengan berpedoman pada Keputusan Kepala Badan Pertanahan Nasional No. 34 tahun 2007 tentang Petunjuk Teknik (Juknis) Penanganan dan Penyelesaian Masalah Pertanahan.

Terdapat 10 (sepuluh) petunjuk teknis dalam keputusan Kepala BPN tersebut, yang mengatur penanganan permasalahan-permasalahan di bidang pertanahan. Salah satunya mengenai Mekanisme Pelaksanaan Mediasi, yang dirumuskan melalui Petunjuk Teknis No. 
5/JUKNIS/DV/2007 tentang Mekanisme Pelaksanaan Mediasi, terbit pada tanggal 31 Mei 2007. Keberadaan aturan tersebut seyogyanya menjadi jalan keluar bagi masyarakat yang memiliki permasalahan di bidang pertanahan. Munir Fuady pernah mengemukakan penyelesaian sengketa melalui mediasi, bahwa :

"Yang dimaksud dengan mediasi adalah suatu proses penyelesaian sengketa berupa negosiasi untuk memecahkan masalah melalui pihak luar yang netral dan tidak memihak, yang akan bekerja dengan pihak yang bersengketa untuk membantu menemukan solusi dalam menyelesaikan sengketa tersebut secara memuaskan kedua belah pihak. Pihak ketiga yang netral tersebut disebut dengan mediator" (Fuady, 2005).

Beberapa ilustrasi kasus yang berhasil diselesaikan melalui mediasi antara lain, yaitu: (Triani, 2019).

a. Sengketa penguasaan harta warisan antara Nasiroh melawan Abdul Wachid berkenaan dengan tanah obyek sengketa berupa satu bidang tanah yang terletak di Desa Pedawang, Kecamatan Bae, Kabupaten Kudus. Perjanjian perdamaian ditandatangani pada tanggal 6 September 2006.

b. Sengketa berkenaan dengan permohonan pemecahan sertipikat tanah Hak Milik (HM) No. 34/Ramanuju, Kelurahan Citangkil, Kecamatan Citangkil, Kota Cilegon, atas nama para ahli waris. Permasalahannya yaitu pemecahan sertipikat tersebut tidak dapat dilakukan karena di atas tanah tersebut sebagian telah dihuni oleh pihak lain. Bahkan telah ada sertipikat lain yang terbit atas tanah tersebut. Akhirnya permasalahan tersebut dapat diselesaikan secara damai dengan ditandatanganinya Perjanjian Penyelesaian Sengketa pada tanggal 12 Juli 2007.

Win-win Solutian merupakan situasi di mana kedua belah pihak sama-sama diuntungkan dalam suatu transaksi atau kesepakatan dan tidak ada pihak yang dirugikan. Mediator dari kantor pertanahan mencari jalan tengah untuk mengakomodasi keadilan pihak yang bersengketa.

Melalui semangat win-win solution, penyelesaian sengketa tidak semata-mata berlandaskan siapa yang memiliki sertifikat. Dalam banyak kasus, seringkali penyelesaian sengketa mengabaikan eksistensi masyarakat lokal yang bertahun-tahun menempati satu wilayah dan mengolah tanah di wilayah tersebut. Masyarakat umumnya akan kalah oleh investor yang memiliki sertifikat atas tanah tersebut.

Proses mediasi oleh mediator dari kantor pertanahan setempat dibagi dalam tiga tahap, yaitu tahap pra mediasi, tahap pelaksaaan mediasi, dan tahap akhir mediasi. 
a. Tahap pra mediasi, mediator membangun kepercayaan diri, menghubungi para pihak, menggali, dan memberikan informasi awal mediasi, fokus pada masa depan, mengkoordinasikan pihak bertikai, mewaspadai perbedaan budaya, menentukan siapa yang hadir, menentukan tujuan pertemuan, kesepakatan waktu dan tempat, serta menciptakan rasa aman bagi kedua belah pihak untuk bertemu dan membicarakan perselisihan mereka (Kraybill, Ronal S., 2006). Peran mediator itu sendiri: Menjalin hubungan dan menjelaskan perannya kepada setiap pihak yang bersengketa; Memilih strategi melalui menjelaskan kekuatan dan kelemahan masing-masing pihak sembari membantu para pihak menganalisa sebagai saran solusi sengketa; Mengumpulkan dan menganalisa informasi latar belakang masalah serta menganalisa sengketa untuk mengidentifikasi pihak terkait sengketa, untuk menentukan pokok masalah dan kepentingan para pihak; Menyusun rencana mediasi, termasuk apabila menghadapi jalan buntu; Membangun kepercayaan dan kerjasama diantara para pihak. Membangkitkan rasa percaya diri para pihak dalam mempersiapkan proses mediasi;

b. Tahap pelaksanaan mediasi adalah tahap di mana pihak-pihak yang bertikai sudah berhadapan satu sama lain dan memulai proses mediasi. Dalam tahap ini, terdapat langkah penting seperti, sambutan pendahuluan mediator, presentasi dan pemaparan kisah para pihak, mengurutkan dan menjernihkan permasalahan, berdiskusi dan negosiasi masalah yang disepakati, menciptakan opsi-opsi, menemukan butir kesepakatan dan merumuskan keputusan, mencatat dan menuturkan kembali keputusan dan penutup mediasi.

Peran mediator pada poin ini adalah: Memulai mediasi sembari menjelaskan prosedur mediasi, meyakinkan para pihak mendapat solusi melalui mediasi, menjelaskan proses mediasi, memberikan kesempatan kepada para pihak untuk tanya jawab; Merumuskan dan menyerahkan agenda mengidentifikasi dan mensepakati permasalahan serta menyusun agenda/ isu-isu yang akan dibahas; Mengungkapkan kepentingan tersembunyi para pihak, secara langsung, yaitu mengajukan pertanyaan secara langsung kepada para pihak dan secara tidak langsung, dengan mendengarkan atau merumuskan kembali pernyataan-pernyataan yang dikemukakan para pihak; mengajukan pilihan penyelesaian sengketa seraya mendorong para pihak untuk terbuka sembari mencari alternatif penyelesaian pemecahan secara bersama; Menganalisa pilihan penyelesaian sengketa; Proses tawar menawar; Mencapai kesepakatan formal, dimana Para pihak menyusun kesepakatan dan prosedur atau rencana pelaksanaan kesepakatan mengacu pada langkah-langkah yang akan ditempuh para 
pihak untuk melaksanakan bunyi kesepakatan dan mengakhiri sengketa; terakhir adalah Tahap Akhir Hasil Mediasi yang merupakan tahap di mana para pihak menjalankan hasilhasil kesepakatan, yang telah dituangkan bersama melalui perjanjian tertulis.

Kelemahan mediasi tersebut apabila salah satu pihak yang bersengketa tidak mau memberikan penjelasannya terkait sengketa yang sudah masuk dibagian seksi sengketa, konflik dan perkara. Di sini mediator tidak bisa melakukan prosedur yang sudah ditentukan.

Proses mediasi yang dipimpin oleh mediator dari kantor pertanahan setempat, para pihak akan diminta untuk memberikan keterangan-keterangan dengan disertai bukti-bukti terkait permasalahan yang ada. Jika mediasi tersebut berhasil maka antar para pihak tersebut akan disusun perjanjian berdasarkan kesepakatan bersama. Namun jika upaya mediasi ternyata tidak berhasil mencapai kesepakatan, para pihak yang bersengketa tetap berhak untuk menyelesaikannya melalui lembaga peradilan (Wirawan, 2019).

Kelemahan mediasi juga terletak pada "kekuatan mengikatnya" putusan mediasi pada sengketa yang murni beraspek keperdataan, putusan penyelesaian sengketa diarahkan sepenuhnya oleh para pihak. Suatu interaksi sosial tidak akan mungkin terjadi apabila tidak memenuhi dua syarat, yaitu kontak sosial (social contact) dan komunikasi (communication). Interaksi sosial dimaksudkan sebagai pengaruh timbal balik antara dua orang atau lebih, yaitu antar invidu satu dengan individu atau kelompok lainnya dalam rangka mencapai tujuan tertentu.

Kitab Undang-undang Hukum Perdata. Pasal 1338 ayat (1) menyebutkan, "Semua persetujuan yang dibuat secara sah sesuai dengan Undang-undang berlaku sebagai Undangundang bagi mereka yang membuatnya". Kata "semua" menunjukkan adanya kebebasan bagi setiap orang untuk membuat perjanjian dengan siapa saja dan tentang apa saja, asalkan tidak dilarang oleh hukum. Artinya setiap ketentuan dalam perjanjian yang telah disepakati para pihak mengikat dan wajib dilaksankan oleh para pihak yang membuatnya.

Putusan atau kesepakatan mediasi tersebut mengikat sehingga dapat langsung dilaksanakan pihak yang bersengketa. Sebagaimana ketentuan dalam Pasal 1338 Kitab Undang-undang Hukum Perdata tiap-tiap kesepakatan atau perjanjian yang dibuat berlaku layaknya Undang-undang bagi para pihak yang membuatnya (Triani, 2019).

Penyelesaian sengketa berdasarkan uraian di atas lebih menekankan pada cara atau proses yang digunakan dalam mediasi untuk diserahkan kepada para pihak yang bersengketa, apakah di dalam penyelesaian sengketa ditempuh cara mediasi atau cara lainnya, bergantung pada kesepakatan para pihak dan dalam hal ini fungsi seorang atau lebih 
selaku perantara (mediator) merupakan hal yang panting yang dapat menjembatani kedua belah pihak yang bersengketa.

Usaha untuk mendamaikan para pihak yang berperkara, dapat dilakukan secara litigasi maupun non-litigasi. Tetapi, perdamaian di luar pengadilan hanya berkekuatan sebagai persetujuan kedua belah pihak belaka yang apabila tidak ditaati salah satu pihak, masih harus diajukan melalui suatu proses di pengadilan. Namun mediasi yang berhasil di luar pengadilan ini, dapat dilegalkan dengan mengajukan gugatan ke Pengadilan Agama yang nantinya akan lahir produk hukum berupa akta perdamaian, seperti yang dijelaskan dalam Pasal 36 PERMA Nomor 1 Tahun 2016.

Penyelesaian sengketa secara mediasi pada khususnya dan penyelesaian sengketa di luar pengadilan pada umumnya, hanya sebatas pada sengketa keperdataan. Hal itu dipertegas oleh Pasal 58 Undang-undang No. 48 Tahun 2009 tentang Kekuasaan Kehakiman, yaitu: "Upaya penyelesaian sengketa perdata dapat dilakukan di luar pengadilan negara melalui arbitrase atau alternatif penyelesaian sengketa”. Hal yang penting agar dalam persengketaan, ditempuh upaya penyelesaian sengketa secara hukum, bukan secara kekerasan atau cara yang melanggar hukum (Talib, 2013).

Secara subtansi, mediasi dalam perkara pertanahan telah dijalankan dengan baik, tetapi hasil yang dicapai kurang efektif karena banyak faktor yang menghambat mediator dalam penyelesaian sengketa pertanahan. Faktor-faktor tersebut antara lain sebagai berikut:

a. Para pihak atau salah satu pihak tidak hadir untuk mengikuti proses mediasi, yang mengakibatkan proses mediasi tidak dapat dilaksanakan. Hal ini sering terjadi dan berpengaruh pada minimnya jumlah perkara yang berhasil dimediasi. Tidak sedikit tergugat yang absen di persidangan, mengakibatkan gagalnya proses mediasi sehingga menjadi suatu penghalang penegakan hukum. Lebih jauh, fenomena tersebut dapat menjadi senjata jitu bagi pihak tidak bertanggung jawab untuk menghindari hukuman yang diberikan hakim. Kehadiran para pihak akan menunjukkan itikad baik ybs dalam menempuh proses perdamaian.

b. Tiap pihak tidak ada yang mau mengalah.

c. Kualitas mediator. Masih banyak hakim di pelosok daerah tanah air, belum mendapat kesempatan mengikuti pelatihan sertifikasi mediator oleh lembaga terakreditasi di luar Mahkamah Agung. Mahkamah Agung belum bisa mengadakan pelatihan mediasi yang cukup untuk semua hakim dikarenakan mediasi belum menjadi program prioritas. 
Suatu sengketa yang sedang terjadi apabila telah mencapai eskalasi, menunjukkan bahwa sengketa tersebut telah mencapai tahap yang akut. Dalam pengertian, di mana sengketa tersebut akan terjadi secara berkelanjutan dan semakin jauh serta sulit untuk diselesaikan. Eskalasi sengketa ini bisa saja terjadi kepada seorang individu, kelompok, komunitas dan bahkan suatu negara. Melalui teori Dean G. Pruitt \& Jeffrey Z. Rubin yaitu Teori Konflik Sosial atau teori Penyelesaian sengketa, maka dapat diketahui bagaimana proses-proses dari suatu peristiwa yang pada saat mencapai kondisi-kondisi tertentu akan menimbulkan sengketa yang berkepanjangan dan semakin rumit. Pihak yang terlibat dalam sengketa akan melakukan berbagai tindakan-tindakan keras berupa strategi untuk mengalahkan lawannya dan terus meningkatkan kekuatannya dengan tujuan agar pihak yang lain kalah, begitu seterusnya sehingga terjadi tindakan yang saling balas-membalas, inilah yang dinamakan eskalasi.

Pada dasarnya sengketa yang terjadi antara satu pihak dengan pihak yang lain dapat disebabkan karena faktor atau hal yang sepele. Apabila diambil tindakan berupa solusi dengan cepat maka konflik itu akan dapat diselesaikan tetapi, akan berbeda apabila sengketa tersebut didiamkan sehingga menimbulkan perasaan yang saling mencurigai maka eskalasi sengketa akan terjadi. Oleh karena itu, dengan mengetahui dan memahami proses-proses yang menimbulkan eskalasi, tentunya diharapkan bisa menghindari hal-hal yang berpotensi menyebabkan timbulnya eskalasi sengketa tersebut.

Upaya demikian dapat dilakukan dengan berpegang pada rumusan sebagaimana dibawah ini yaitu:

a. Contending (bertanding), yaitu mencoba menerapkan suatu solusi yang lebih disukai oleh salah satu pihak atas pihak yang lainnya;

b. Yielding (mengalah), yaitu menurunkan aspirasi sendiri dan bersedia menerima kekurangan dari yang sebetulnya diinginkan;

c. Problem solving (pemecahan masalah), yaitu mencari alternatif yang memuaskan dari kedua belah pihak.

d. With drawing (menarik diri), yaitu memilih meninggalkan situasi sengketa, baik secara fisik maupun psikologis.;

e. In action (diam), yaitu tidak melakukan apa-apa.

Berdasarkan uraian singkat di atas, aspek pertanahan memerlukan perlindungan hukum. Dengan kata lain, hukum akan senantiasa mengatur, melindungi, mengayomi, menertibkan, mengarahkan, dan sekaligus merekayasa nilai dan sikap manusia terhadap 
tanah, dan bukan karena kekuasaan (politik atau ekonomi) semata. Peran mediator dari kantor pertanahan merupakan faktor penentu kepastian hukum dan keadilan dalam penyelesaian sengketa tanah.

\section{Simpulan}

Sengketa dapat terjadi baik secara individu maupun kelompok hingga kombinasi keduanya. Dengan kata lain, sengketa dapat bersifat publik, keperdataan, hingga dapat terjadi melalui lingkup lokal, nasional maupun internasional. Teori Penyelesaian Sengketa Dean G. Pruitt dan Jeffrey Z. Rubin mengemukakan bahwa, sengketa adalah persepsi mengenai perbedaan kepentingan atau suatu kepercayaan bahwa aspirasi pihak-pihak yang berkonflik tidak dapat dicapai secara simultan, oleh karena itu perlu pemecahan masalah, untuk mencari alternatif yang menguntungkan kedua belah pihak.

Latar belakang masyarakat memilih proses mediasi itu sendiri, selain karena biaya ringan, cepat dan mudah, serta putusan akhir dari mediasi jelas. Mediasi merupakan cara bermusyawarah dan bermufakat, untuk mencapai kesepakatan bagi para pihak bersengketa, melalui perantaraan mediator yang membutuhkan akta perdamaian sebagai putusan mediasi yang didaftarkan dan dikuatkan oleh Pengadilan Negeri.

\section{DAFTAR PUSAKA}

\section{Buku:}

A. Prasetyo, "Prinsip Pengadaan Tanah Bagi Kepentingan Umum," Administrative Law \& Governance Journal, vol. 1, no. 3, pp. $259 \quad$ - 267, Dec. 2018. https://doi.org/10.14710/alj.v1i3.259 - 267

Absori. (2014). Penyelesaian Sengketa Lingkungan Hidup: Sebuah Model Penyelesaian Lingkungan Hidup dengan Pendekatan Partisipatif. Surakarta: Muhammadiyah University Press.

Achmad, Y. \& M. F. N. (2013). Dualisme Penelitian Hukum Normatif dan Empiris. Yogyakarta: Pustaka Pelajar.

Effendie, B. (1983). Pendaftaran Tanah Di Indonesia dan Peraturan-Peraturan Pelaksanaanya. Bandung: Penerbit Alumni.

Fuady, M. (2005). Pengantar Hukum Bisnis, Menata Bisnis Modern di Era Global. Bandung: Citra Aditya Bakti.

Gautama, S. (1996). Aneka Hukum Arbitrase Kearah Indonesia Yang Baru. Bandung: Citra Aditya 
Bakti.

Irianto, S. (n.d.). Memperkenalkan Studi Sosio Legal Dan Implikasi Metodologisnya.

Kraybill, Ronal S., A. F. E. dan R. A. E. (2006). Peace Skill, Panduan Mediator terampil Membangun Perdamaian. Yogyakarta: Kanisius.

Mertokusumo, S. (2012). Teori Hukum. Yogyakarta: Cahaya Atma Pustaka.

Muhammad, A. (2004). Hukum dan Penelitian Hukum. Bandung: Citra Aditya Bakti.

Nasution. (2008). Metode Research: Penelitian Ilmiah. Jakarta: Bumi Aksara.

Pruitt, Dean G \& Z. Rubin. (2004). Konflik Sosial. Yogyakarta : Pustaka Pelajar.

Rahmadi, T. (2010). Mediasi Penyelesaian Sengketa Melalui Pendekatan Mufakat. Jakarta: PT. Radja Grafindo Persada.

Soemitro, R. H. (1998). Metode Penelitian Hukum dan Jurimetri. Jakarta: Ghalia Indonesia.

Sutiyoso, B. (2006). Penyelesaian Sengketa Bisnis. Yogyakarta: Citra Media.

Triani, R. (2019). Selesaikan Sengketa Pertanahan Anda Melalui Mekanisme Mediasi.

Usman, R. (2002). Pilihan Penyelesaian Sengketa di Luar Pengadilan. Bandung: Citra Aditya Bakti.

\section{Artikel Jurnal}

Asmawati. (2004). Mediasi Salah Satu Cara dalam Penyelesaian Sengketa Pertanahan. Jurnal Imu Hukum, Maret 2004.

Busroh, F. F. (2017). Mediasi Sosial Dalam Menyelesaikan Konflik Lahan Milik Masyarakat Adat Di Indonesia. Lex Jurnalica, 14 Nomor 1.

Talib, I. (2013). Bentuk Putusan Penyelesaian Sengketa Berdasarkan Mediasi. Jurnal Lex et Societatis, Vol.I/No.1.

Chulaemi, A. (1992). Pengadaan Tanah Untuk Keperluan Tertentu Dalam Rangka Pembangunan. Majalah Masalah-Masalah Hukum, Nomor 1 Tahun 1992, Nomor 1.

Pahlefi. (2014). Analisis Bentuk-Bentuk Sengketa Hukum atas Tanah Menurut Peraturan PerUndang-undangan di Bidang Agraria. Majalah Hukum Forum Akademika, Vol. 25 Maret.

\section{Sumber lain:}

Irzan. (2012). Wawancara dengan Dosen Fakutas Hukum Universitas Nasional Jakarta tanggal 12 Oktober 2019. Jakarta.

Wirawan, Y. (2019). Wawancara dengan Yudith Wirawan, S.H., M.H., Hakim Pengadilan Negeri 
Wates tanggal 12 Oktober 2019. Yogyakarta. 